Volume 13

Number 4 Vol. 13, No. 4 Climate Change

Article 13 and Global Security

\title{
The CIA War in Kurdistan: The Untold Story of the Northern Front in the Iraq War. By Sam Faddis. Havertown, PA: Casemate Publishers, 2020.
}

Mark J. Roberts

Middle East Area Specialist and Terrorism Analyst

Follow this and additional works at: https://digitalcommons.usf.edu/jss

pp. 164-167

\section{Recommended Citation}

Roberts, Mark J.. "The CIA War in Kurdistan: The Untold Story of the Northern Front in the Iraq War. By Sam Faddis. Havertown, PA: Casemate Publishers, 2020.." Journal of Strategic Security 13, no. 4 (2020) : 164-167. DOI: https://doi.org/10.5038/1944-0472.13.4.1898 Available at: https://digitalcommons.usf.edu/jss/vol13/iss4/13

This Book Review is brought to you for free and open access by the Open Access Journals at Digital Commons @ University of South Florida. It has been accepted for inclusion in Journal of Strategic Security by an authorized editor of Digital Commons @ University of South Florida. For more information, please contact digitalcommons@usf.edu. 


\section{The CIA War in Kurdistan: The Untold Story of the Northern}

Front in the Iraq War. By Sam Faddis. Havertown, PA: Casemate Publishers, 2020. 


\section{The CIA War in Kurdistan: The Untold Story of the Northern Front in the Iraq War. By Sam Faddis. Havertown, PA: Casemate Publishers, 2020. ISBN 978- 1-61200-834-9. Photographs. Pp. xiii, 226. \$34.95.}

Over the past few decades, the story of the U.S.-Kurdish relationship in northern Iraq has received little attention. In both the 1990 s and early 200os, the U.S. worked with the Kurds, promising them protection from Saddam Hussein, weapons, and materiel support that never appeared. Sam Faddis' much-needed book fills a gap in this history that outlines the outstanding initiative of field operatives juxtaposed against D.C.'s bureaucratic inertia and tone deaf apparatchiks.

Faddis leaves the reader with a well-written tome that reads like a heartstopping thriller, but what he recounts actually occurred. Faddis is a former U.S. Army combat arms officer and retired Central Intelligence Agency (CIA) officer with decades of undercover experience in the Middle East and South Asia. He knows the area and its customs and cultures well.

Faddis recounts his first-hand experience as a CIA officer at CIA Headquarters (HQ) in 2002 who volunteered to set up a base in northern Iraq to work with Kurdish allies to prepare for the invasion of Iraq. Based on his extensive experience in the area, he had the expertise and acumen to operate in Iraqi Kurdistan.

As he built his team, he began to raise basic questions and practical concerns about how to carry out his mission. His repeated queries about how to get weapons and supplies to Kurds in northern Iraq through Turkey were waived off by CIA bureaucrats and the White House. He repeatedly highlights his frustration with the disconnects between perceptions and the on-the-ground truth in northern Iraq. CIA HQ told him to prepare pallets of supplies to take to the Kurds through Turkey. Citing longstanding Turkish-Kurdish mutual loathing, Faddis pointed out that Ankara would never permit this to take place. His chain of command told him not to worry, that they would make it so. Time and again, Faddis was correct, but his chain of command never seemed to be able to acknowledge this. 
Arriving in northern Iraq after an arduous journey through Turkey marred by bureaucratic roadblocks from both Ankara and Washington, Faddis and his team established a presence and initiated liaison with leaders in the various Kurdish factions. Kurdish leaders were suspicious of promises of U.S. air support based on many years of hollow promises.

I was talking to a man who had lost countless members of his own clan to the hands of Saddam. Kurdistan and its painful history were his life. He wasn't interested in what the National Security Council was putting into PowerPoint presentations back home. He wanted brass tacks and something tangible. Talking about commitment was one thing; demonstrating commitment was another (54).

Faddis employed his tradecraft to demonstrate he was sincere and would do what he could. He did promise that he was in country to help remove Saddam Hussein and would not leave until that had occurred. Although Kurdish allies were not entirely convinced, they agreed to work with the CIA team. Faddis and his team began to operate in northern Iraq working alongside their Kurdish allies. They had operational intelligence teams collecting intelligence, running human sources, and sending hundreds of intelligence reports back to CIA HQ. These reports outlined in detail Iraqi capabilities, limitations, and opportunities the U.S. had in country to undermine Saddam Hussein's security apparatus.

Faddis repeatedly requested material support from CIA HQ to fulfill Kurdish requests. Washington repeatedly ignored the reality that Ankara had a de facto veto on anything passing from southeastern Turkey into northern Iraq. In spite of this lack of support, Faddis and his team continued intelligence collections and recruitments. Their counterintelligence and counterterrorism reports filled an intelligence void about ground truth in Iraqi Kurdistan. To Faddis' amazement, none of this intelligence seemed to have any impact on US. policy, and, to add insult to injury, none of this intelligence got to U.S. military special forces, who needed that situational awareness to effectively operate in denied territory.

As U.S. military special forces arrived in the area, Pentagon edicts, bureaucratic snafus, and lack of understanding about local conditions led the military leadership to downplay the necessity of effective liaison relationships with the in-country CIA team that had been operating for 
months in a bare base environment. Some of Faddis' frustration stemmed from opposing viewpoints. Faddis viewed the Kurds as crucial allies in the fight to overthrow Saddam Hussein. The military viewed the Kurds as a force to be contained in order to avoid inflaming the passions of the Iraqi people.

Despite a seemingly endless set of queries about Saddam Hussein's WMD capability, Faddis and his team never found any evidence that the Iraqi dictator indeed had a WMD capability. CIA sources cited a WMD capability as a reality, but never could provide the CIA with any concrete evidence of the same. Washington bureaucrats never seemed to acknowledge this fact.

Faddis expressed great frustration that despite the reliability of his team's sources on the ground, Washington bureaucrats placed great trust and confidence in Iraqi exile Ahmed Chalabi, who had no access or credibility within Iraq. Chalabi had influence in D.C. and with myriad lobbying factions on K Street.

Chalabi was also a bald-faced liar when it came to intelligence. To feather his own nest and to steer American policy over the years, he had fabricated all kinds of information and passed it to a succession of CIA officers. In response, the CIA had issued a "burn notice" on him, which, before it became a cool name for a silly TV show, meant that we had washed our hnads of him. We would not meet him. We would not deal with him (150).

According to Faddis, Chalabi's façade not only charmed, it influenced U.S. policy in Iraq in spite of Chalabi's lack of base or support. Chalabi did end up as a media darling who received large sums of money due to his intense lobbying efforts, while Faddis and his team left Iraq and went on to other assignments. The quality and quantity of intelligence they produced was successful beyond all expectations. Nonetheless, their efforts seem to have been whitewashed away by events elsewhere in the country and the region.

Faddis' account is a brutally honest account of austere field conditions, D.C. bureaucratic fumbling, and an inability to keep faith with a constant and loyal Kurdish ally. His book tells a story that, although unwelcome and unflattering to the U.S., needs to be told. 
Mark J. Roberts, Middle East Area Specialist and Terrorism Analyst 